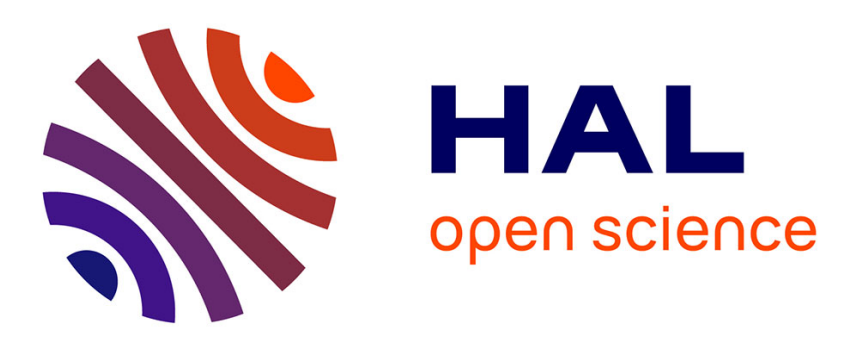

\title{
Effect of a temperature gradient on Sphagnum fallax and its associated living microbial communities: a study under controlled conditions.
}

Vincent E. J. Jassey, Daniel Gilbert, Philippe Binet, Marie-Laure Toussaint, Geneviève Chiapusio

\section{To cite this version:}

Vincent E. J. Jassey, Daniel Gilbert, Philippe Binet, Marie-Laure Toussaint, Geneviève Chiapusio. Effect of a temperature gradient on Sphagnum fallax and its associated living microbial communities: a study under controlled conditions.. Canadian Journal of Microbiology, 2011, 57 (3), pp.226-235. hal-00682501v2

\author{
HAL Id: hal-00682501 \\ https://hal.science/hal-00682501v2
}

Submitted on 26 Mar 2012

HAL is a multi-disciplinary open access archive for the deposit and dissemination of scientific research documents, whether they are published or not. The documents may come from teaching and research institutions in France or abroad, or from public or private research centers.
L'archive ouverte pluridisciplinaire HAL, est destinée au dépôt et à la diffusion de documents scientifiques de niveau recherche, publiés ou non, émanant des établissements d'enseignement et de recherche français ou étrangers, des laboratoires publics ou privés. 
1 Effect of a temperature gradient on Sphagnum fallax and its associated

2 living microbial communities: a study under controlled conditions

3

4 Vincent EJ Jassey, Daniel Gilbert, Philippe Binet, Marie-Laure Toussaint and

5 Geneviève Chiapusio

6 Laboratory of Chrono-Environnement, University of Franche-Comté UMR UFC/CNRS

7 6249 USC INRA, Montbéliard 25211 cedex, France

$8 \quad$ vincent.jassey@univ-fcomte.fr

9 daniel.gilbert@univ-fcomte.fr

10 philippe.binet@univ-fcomte.fr

11 marie-laure.toussaint@pu-pm.univ-fcomte.fr

12 genevieve.chiapusio@univ-fcomte.fr

13

14

15

16

17

18

19

e-mail address: vincent.jassey@univ-fcomte.fr

Correspondence to Vincent Jassey

Laboratory of Chrono-Environnement, University of Franche-Comté UMR UFC/CNRS

6249 USC INRA, 4 place Tharaddin, Montbéliard 25211 cedex, France

Tel : +33 381994694 ; fax : +33 381994661
20

21

22

23

24

25

26

27

28

29

30 
31 Abstract

32 Microbial communities living in Sphagnum are known to constitute early indicators of 33 ecosystem disturbances, but little is known about their response (including their trophic 34 relationships) to climate change. A microcosm experiment was designed to test the 35 effects of a temperature gradient $\left(15,20\right.$ and $\left.25^{\circ} \mathrm{C}\right)$ on microbial communities including different trophic groups (primary producers, decomposers and unicellular predators) in Sphagnum segments (0-3 cm and 3-6 cm of the capitulum). Relationships between microbial communities and abiotic factors $(\mathrm{pH}$, conductivity, temperature, and polyphenols) were also studied.

The density and the biomass of testate amoebae in Sphagnum upper segments increased

41 and their community structure changed in heated treatments. The biomass of testate amoebae was linked to the biomass of bacteria and to the total biomass of other groups added and, thus, suggests that indirect effects on the food-web structure occurred. Redundancy analysis revealed that microbial assemblages differed strongly in Sphagnum upper segments along a temperature gradient in relation to abiotic factors.

46 The sensitivity of these assemblages made them interesting indicators of climate change. Phenolic compounds represented an important explicative factor in microbial assemblages and outlined the potential direct and/or indirect effects of phenolics on microbial communities.

51 Keywords: Sphagnum, testate amoebae, temperature gradient, phenolic compounds, bioindicators 


\section{Résumé}

56 Les microorganismes des sphaignes sont connus comme indicateurs précoces des

57 perturbations environnementales. Or, peu d'études portent sur l'influence de la température sur ces communautés. Dans cette étude, l'effet d'un gradient de températures $\left(15,20\right.$ et $\left.25^{\circ} \mathrm{C}\right)$ sur les microorganismes des sphaignes, incluant différent groupes trophiques (producteurs primaires, décomposeurs, micro-prédateurs), a été testé dans les différentes parties des sphaignes ( 0 à $3 \mathrm{~cm}$ et 3 à $6 \mathrm{~cm}$ du capitulum). Les relations entre les microorganismes et les facteurs abiotiques ( $\mathrm{pH}$, conductivité, température, polyphénols) ont également été analysées.

64 La densité et la biomasse des amibes à thèque ont augmenté dans les parties supérieures 65 des sphaignes. Une modification de la structure de leur communauté a aussi été mise en 66 évidence. La biomasse des amibes à thèque est apparue liée à celle des bactéries et à la 67 biomasse additionnée des autres groupes, suggérant des effets indirects de la température sur les relations trophiques. Les analyses par redondance ont révélé que la structure des communautés microbiennes variait entre les différents traitements dans les parties supérieures des sphaignes. Ainsi, les communautés microbiennes des sphaignes apparaissent comme un outil intéressant quant au suivi in situ des changements climatiques. Les polyphénols ont également été identifiés comme un facteur explicatif important de la structure des communautés microbiennes, montrant ainsi leurs effets

74 potentiels sur les microorganismes des sphaignes.

76 Mots-clés : Sphaignes, amibes à thèque, gradient de température, composés 77 phénoliques, bioindicateurs 


\section{Introduction}

80 Climatic change models cover a wide range of temperature-increase scenarios $\left(2^{\circ} \mathrm{C}\right.$ up 81 to $8^{\circ} \mathrm{C}$ ), especially at high latitudes where the majority of Sphagnum-peatlands occurs 82 (Gorham, 1991; IPCC, 2007). Peatlands are complex ecosystems, because of the

83 diversity of habitats and micro-habitats allowing the establishment of diverse communities (Rydin and Jeglum, 2006). Studying the impact of climate change on these ecosystems remains particularly difficult and complex because of several biological and chemical parameters interacting (Davidson and Janssens, 2006). Some microcosm studies were elaborated to test the impact of a temperature increase on Sphagnum plant communities (Breuwer et al., 2008, 2009). However, such studies were carried out at the scale of simple organisms or populations and did not incorporate the interactions between different populations. Thus, a simplified ecosystem including different trophic levels could be then an interesting approach to better understand the effect of a temperature increase. In this context, the use of microbial communities living in Sphagnum represents a simplified ecosystem (Nguyen-Viet et al., 2007; Meyer et al., 2009). Sphagnum mosses are ubiquitous, cosmopolitan, and characterized peatlands (Shaw et al., 2003; Rydin and Jeglum, 2006). Moreover, Sphagnum mosses shelter a large number of microbial species belonging to the different trophic groups, including bacteria, algae, testate amoebae, ciliates, or fungi, which have a short generation time (hours up to few weeks) (Schönborn, 1986; Gilbert et al., 1998).

Some studies have demonstrated that the richness and density of single microbial groups (e.g. testate amoebae, microalgae) and/or the structure of microbial communities living in Sphagnum are affected by environmental perturbations such as nitrogen addition and atmospheric pollution (Howell and South, 1981; Gilbert et al., 1998; Mitchell et al., 2003; Nguyen et al., 2007, 2008). In addition, the integration of 
104 testate amoebae into an experimental model is interesting because they feed on a wide

105 range of preys, (i.e. bacteria, fungi, organic matter, algae, other protozoa) and could integrate ecosystem perturbations (Gilbert et al., 2000, 2003). Thus, such a simplified system not only would notably give insight into the interactions between species but also would incorporate biotic and abiotic factors (including phytochemicals) interactions between Sphagnum and its associated microbial communities. communities are rarely studied. However, phenolic compounds (secondary metabolites) produced by plants play an important role in the interaction of vegetation with its 113 environment (Hättenschwiler and Vitousek, 2000; Chiapusio et al., 2005). For example, 114 in humus spruce forests, such compounds are implicated in the increase of several 115 microbial communities (i.e. cellulose hydrolysers) and in the decrease of others (i.e. 116 bacteria) (Souto et al., 2000, 2001). Some studies have addressed phenolic production 117 by Sphagnum (e.g. Rasmussen et al., 1995), more specifically the phenolics weakly and 118 primarily bound to the cell wall (Verhoeven and Liefveld, 1997). Because of Sphagnum 119 morphology and anatomy, water-soluble phenolics can be easily released in Sphagnum 120 environments. Recently, Jassey et al. (2011) demonstrated that such compounds were 121 involved in the fine-scale microdistribution of testate amoebae along an ecological 122 gradient. A multitude of environmental factors cause significant shifts in the quantity of 123 phenolic compounds in vascular plants (e.g. UV-B; Spitaler et al., 2008), but they are 124 understudied in Sphagnum. The patterns of phenolic compounds at the surface of 125 Sphagnum layers may be susceptible to temperature increase and to interactions with 126 microbial communities living in Sphagnum. In this study, we assessed the response of vertical patterns of microbial 128 communities living in Sphagnum and the relationships among microbial communities, 
129 temperature, and total phenolic compounds along a temperature gradient. The

130 abundance and the structure of microbial communities and the concentrations of

131 phenolic compounds were quantified in Sphagnum peat cores placed at 3 different

132 temperatures $\left(15,20\right.$, and $\left.25^{\circ} \mathrm{C}\right)$ after 8 weeks in a growth chamber. According to the

133 gradient of temperature, we addressed the following hypotheses: $(i)$ that the structure

134 and biomass of microbial communities would vary among temperature treatments and

135 Sphagnum layers (upper and lower), (ii) that the effect of temperature would be

136 different for each microbial group according to their trophic position, and (iii) that total

137 phenolic compound concentrations quantified in Sphagnum fallax would change along

138 the temperature gradient and Sphagnum layers, and would explain a similar fraction of

139 the community data as other environmental factors.

140

141 Materials and Methods

142 Sphagnum sampling and experimental setup

143 Sphagnum fallax was collected in a peat bog in the Jura Mountains (Sur-les-Seignes,

144 Frambouhans-Les Ecorces, France, $47^{\circ} 18^{\prime} \mathrm{N}, 6^{\circ} 79^{\prime} \mathrm{E}$ ) at an altitude of $846 \mathrm{~m}$ above sea

145 level on $19^{\text {th }}$ October 2007 (temperature $10^{\circ} \mathrm{C}$ ). The climate of the area is characterized

146 by cold winters (an average of $-2.4^{\circ} \mathrm{C}$ in January) and mild summers (an average of

$14714.6^{\circ} \mathrm{C}$ in July). The annual mean temperature of the region is about $6.6^{\circ} \mathrm{C}$. The annual

148 amount of precipitations is $1417 \mathrm{~mm}$, and the duration of snow cover is an average of

14950 day. year ${ }^{-1}$. Surfaces of S. fallax as homogenous and pure as possible were selected.

150 Sixteen Sphagnum peat cores $(25 \mathrm{~cm}$ x $15 \mathrm{~cm})$ were randomly sampled with a knife.

Four peat cores were assigned in quadruplicates to described the initial stage (IS)

152 and 12 peat cores for the three treatments 15,20 and $25^{\circ} \mathrm{C}$ (designated $\mathrm{T} 15, \mathrm{~T} 20$ and 
153 T25, respectively). A large gradient of temperature was chosen to observe the response

154 of communities. Peat cores were randomly placed between the different levels of the

155 growth chamber (Cryonext RTH600). General conditions selected were a relative 156 humidity of $>70 \%$, a light intensity of $120 \mu \mathrm{mol} \cdot \mathrm{s}^{-1} \cdot \mathrm{m}^{-2}$, and a photoperiod of $12 \mathrm{~h}$

157 (light)/12h (dark). Each treatment corresponded to 1 level of the growth chamber. For 158 each treatment, peat cores were placed in 1 big tray full of water (water level $=20 \mathrm{~cm}$ ) 159 and were humidified with a standard nutrient solution (Volvic water). The water depth 160 was kept at $2 \mathrm{~cm}$ below the top of Sphagnum and readjusted with demineralized water 161 every 2 days. The average relative humidity of Sphagnum was around 90\% in 162 Sphagnum segments for each treatment during the experiment. The $15^{\circ} \mathrm{C}$ temperature 163 corresponded to the temperature of the growth chamber. The $20^{\circ} \mathrm{C}$ and $25^{\circ} \mathrm{C}$ 164 temperatures were obtained by heating the water of the tray with respectively 2 thermo165 divers of 50 and $200 \mathrm{~W}$ and 2 thermo-divers of $200 \mathrm{~W}$. Moreover, aquarium pumps $166\left(5 \mathrm{~L} \cdot \mathrm{min}^{-1}\right)$ were installed in the warm trays to obtain homogeneous temperatures. The 167 position of peat cores was changed in each tray every 2 days to avoid experimental 168 differences. The temperature was recorded several times a day during the experiment in 169 each peat cores. The water chemistry ( $\mathrm{pH}$, conductivity and Eh potential) was also 170 measured in each peat cores every 2 days.

171 Before and after 8 growing weeks 20 S. fallax were sampled in each peat cores 172 and cut into 2 layers from the capitulum 0-3 cm (upper segments) and 3-6 $\mathrm{cm}$ (lower 173 segments). For microbial analysis, the samples were fixed in $20 \mathrm{~mL}$ of glutaraldehyde 174 (2\% final concentration). No mosses were taken from the $5 \mathrm{~cm}$ bordering peat cores to 175 avoid a border effect. 
178 Phenolic compounds were extracted from lyophilized mosses following two methods as

179 described in Jassey et al. (2011) and commonly used in phytochemical interactions 180 (Waterman et al., 1994; Macheix et al., 2005). Water-soluble phenolics (hereafter "free 181 phenolics") were extracted using distilled water and corresponded to phenolics 182 susceptible to directly interact with microorganisms. Primarily bound phenolics 183 (hereafter "bound phenolics") were extracted using ethanol/distilled water solution 184 (80:20, v/v) and mainly corresponded to phenolic acids slightly bound to cell-wall. 185 Thereafter, free and bound total phenolic contents were quantified with the Folin186 Ciocalteau reagent and were expressed in milligrams of equivalent gallic acid $\left(A_{760}\right)$ 187 (Gallet and Lebreton, 1995).

Microbial organisms were extracted from S. fallax with the standard method of Nguyen-

190 Viet et al. (2007). Each sample was shaken for 1 min on a vortex and then Sphagnum 191 mosses were pressed to extract microorganisms (first solution). The mosses were then 192 soaked again with $20 \mathrm{~mL}$ of glutaraldehyde ( $2 \%$ final concentration), shaken a second 193 time on a vortex, and pressed to extract Sphagnum leachate. The leachate was settled for 194 12h, and afterward the supernatant was added to the Sphagnum and the material on the 195 bottom was added to the first solution. The process was repeated 6 times, and all 196 fractions were combined to obtain a final composite sample of $40 \mathrm{~mL}$. The remaining 197 fraction was dried at $80^{\circ} \mathrm{C}$ for $48 \mathrm{~h}$ and weighted to express microbial density in grams 198 of dry weight of Sphagnum.

199 Primary producers, fungi and unicellular predators: a $3 \mathrm{~mL}$ subsample of the 200 final composite sample was settled for $2 \mathrm{~h}$ in a plankton chamber and analyzed at x 400 
magnification by inverted microscopy (Olympus IX71) following Uthermöhl's method

202 (1958). The whole slide was analyzed and the different groups of cyanobacteria, 203 microalgae, unicellular predators (flagellates, testate amoebae and ciliates) and fungi

204 hyphae and spores were counted and measured. For testate amoebae, only living tests 205 were counted.

206 Bacteria: a $1 \mathrm{~mL}$ subsample of the final composite sample was stained with 50 $207 \mu \mathrm{L}$ of 4,6 diamino-2-phenylindol (DAPI, $0.2 \%$ of final concentration) for $15 \mathrm{~min}$ in the 208 dark, filtered through $0.2 \mu \mathrm{m}$ black membrane filters, and examined by epifluorescence 209 microscopy at x 1000 magnification (Porter and Feig, 1980). Bacteria numbers and size 210 were estimated with an image analysis program (LUCIA 4.0). For each sample, 211 between 8 and 35 photographic grips were observed. The number of bacteria cells 212 counted and measured was situated between 514 and 1132. This direct counting using 213 DAPI gave the total density of bacteria.

214 The biovolume of each community was estimated by assuming geometrical 215 shapes and converted to carbon using the following conversion factors: bacteria, $1 \mu \mathrm{m} 3$ $216=5.6 \times 10^{-7} \mu \mathrm{gC}$ (Bratbak, 1985); cyanobacteria and microalgae, $1 \mu \mathrm{m} 3=1.2 \times 10^{-7} \mu \mathrm{g} \mathrm{C}$ 217 (Borsheim and Bratbak, 1987); ciliates and testate amoebae, $1 \mu \mathrm{m} 3=1.1 \times 10^{-7} \mu \mathrm{g} \mathrm{C}$ 218 (Weisse et al., 1990); fungi, $1 \mu \mathrm{m} 3=2.5 \times 10^{-7} \mu \mathrm{g} \mathrm{C}$ (Gilbert et al., 1998). The data 219 were expressed as micrograms of Carbon per gram of Sphagnum dry mass per square 220 centimeter $\left(\mu \mathrm{g} \mathrm{C} .(\mathrm{g} \mathrm{DW})^{-1} \cdot \mathrm{cm}^{-2}\right)$.

221 Numerical analysis

222 Since the data distributions of microbial communities, phenolic compounds and water 223 chemistry were not normal and statistically dependant, a non-parametric 2-way analysis 224 of variance test (Friedman test) was used to determine the differences among the 225 temperatures (T15, T20 and T25). 
To reduce the influence of dominant taxa in the multivariate analysis, carbon

227 biomass of microbial communities was transformed using the relation $\operatorname{Ln}(x+1)$

228 (Nguyen-Viet et al., 2007). Multiple factor analysis (MFA) was used to assess the

229 general structure of the data and to determine the relationships among the 2 microbial

230 community's data sets (upper and lower) and the 3 environmental variables data sets

231 (water chemistry, temperature and phenolics). MFA was chosen because it allows the

232 simultaneous coupling of several groups or subsets of variables defined on the same

233 objects (Escofier and Pagès, 1994). The MFA was performed in 2 steps. Firstly, a first

234 principal component analysis (PCA) was applied to the whole set of variables in which

235 each subset was weighted by dividing all its elements by the first eigenvalue obtained

236 from its PCA. Secondly, the normalized subsets were assembled to form a unique

237 matrix and a second PCA was performed on this matrix. Euclidean distances of global

238 PCA were then used in MFA to perform cluster analysis according to the Ward method,

239 and the resulting dendrogram was projected in the MFA ordination space. This analysis

240 revealed the main differences in the structure of the data described by all biotic and

241 abiotic subsets of variables (Lamentowicz et al., 2010).

We assessed the relationships among the microbial communities in the upper

243 and lower sampling depth and the 3 sets of environmental variables: $(i)$ water chemistry

244 (pH, Eh potential and conductivity), (ii) temperature and (iii) phenolic compounds

245 (bound and free). The ordination patterns of microbial communities and their causal

246 relationships to environmental data-sets were assessed using redundancy analysis

247 (RDA) (Ter Braak and Simlauer, 1998). A forward selection of explanatory variables

248 was computed for each of the Sphagnum segments, using automatic stepwise model

249 building for constrained ordination methods ("ordistep" function). The proportion of 250 variance explained by environmental variables was quantified using variance 
251 partitioning. Adjusted $\mathrm{R}^{2}$ were used in all RDA to estimate the proportion of explained

252 variance by each environmental variable (Peres-Neto et al., 2006).

253 All multivariate analyses were performed with the software R (R Development

254 Core Team, 2010) using the vegan (Oksanen et al., 2010) and FactoMineR (Husson et 255 al., 2009) packages.

257 Results

258 Environmental variables

259 During the experiment, temperatures recorded were stable in both Sphagnum segments 260 with $14.8 \pm 0.4^{\circ} \mathrm{C}$ for $\mathrm{T} 15,19.4 \pm 0.3^{\circ} \mathrm{C}$ for $\mathrm{T} 20$ and $23.9 \pm 0.5^{\circ} \mathrm{C}$ for $\mathrm{T} 25$. The 261 conductivity and the Eh potential were significantly lower $(P<0.05)$ in T15 $(30 \pm 9.4$ $262 \mu \mathrm{S} . \mathrm{cm}^{-1}$ and $370.1 \pm 16.2 \mathrm{mV}$, respectively) than in T20 and T25 $\left(19.1 \pm 3 \mu \mathrm{S} . \mathrm{cm}^{-1}\right.$ and $263335.5 \pm 20 \mathrm{mV}$, respectively). The $\mathrm{pH}$ was stable during the experiment $(\mathrm{pH}=4.1 \pm 0.5$ 264 in IS, T15, T20 and T25).

266 Temperature effect on total phenolic compounds

267 The concentrations in the 3 treatments were 1.5 times higher in upper segments (bound: 268 an average of $2.6 \mathrm{mg} \cdot \mathrm{g}^{-1} \mathrm{DW}$, free: an average of $1.8 \mathrm{mg} \cdot \mathrm{g}^{-1} \mathrm{DW}$ ) than in lower 269 segments (bound: an average of $1.6 \mathrm{mg} \cdot \mathrm{g}^{-1} \mathrm{DW}$, free: an average of $0.7 \mathrm{mg} \cdot \mathrm{g}^{-1} \mathrm{DW}$ ) 270 (Table 1). Bound phenolics produced by S. fallax did not significantly differ between 271 the upper and the lower segments, with the different temperatures. Free phenolics were 272 significantly higher in upper segments $(P<0.04)$ for T25 than for the other treatments. 273 A significant relation was also found between bound and free phenolics $(P<0.001, \mathrm{r}=$ $2740.62)$. 
276 The main change in the total biomass of microbial communities occurred in the upper 277 segments of Sphagnum whereas it was quite stable in lower segments (Fig. 1). Indeed 278 the total biomass in upper segments was nearly twice as high with elevated temperature 279 (T15: $1400 \mu \mathrm{g} \mathrm{C} .(\mathrm{g} \mathrm{DW})^{-1} \cdot \mathrm{cm}^{-2}, \mathrm{~T} 20$ and T25: 1700 and $2700 \mu \mathrm{g} \mathrm{C} .(\mathrm{g} \mathrm{DW})^{-1} . \mathrm{cm}^{-2}, P<$ $2800.01)$

Primary Producers. The biomass of primary producers did not significantly vary between T15, T20, and T25 (Fig. 1). The biomass of microalgae was $85 \pm 31 \mu \mathrm{g} \mathrm{C.(g}$ $\mathrm{DW})^{-1} \cdot \mathrm{cm}^{-2}$ in upper segments and $106 \pm 31 \mu \mathrm{g} \mathrm{C} .(\mathrm{g} \mathrm{DW})^{-1} \cdot \mathrm{cm}^{-2}$ in lower segments. The community was dominated by the same species along Sphagnum segments in any treatments. Chlorophyceae (e.g. Cylindrocystis sp and Penium sp) and Bacillariophycae (e.g. Pinnularia viridis) were the main identified genus. Cyanobacteria represented a small proportion $(<5 \%)$ of the total biomass along Sphagnum segments in any treatments with an average biomass of $50 \pm 17 \mu \mathrm{g} \mathrm{C} .(\mathrm{g} \mathrm{DW})^{-1} \cdot \mathrm{cm}^{-2}$ in upper segments and $31 \pm 10 \mu \mathrm{g} \mathrm{C}$. $(\mathrm{g} \mathrm{DW})^{-1} . \mathrm{cm}^{-2}$ in lower segments. Cyanobacteria were dominated by Chroococcales (e.g. Chroococcus giga) and Nostocales (e.g. Anabaenae cylindrica and Aphanothece nidulans) along Sphagnum segments. segments with elevated temperature (T20 and T25) than in T15. For example, bacterial biomass increased from $200 \mu \mathrm{g} \mathrm{C.}(\mathrm{g} \mathrm{DW})^{-1} \cdot \mathrm{cm}^{-2}$ in $\mathrm{T} 15$ to $440 \mu \mathrm{g} \mathrm{C} .(\mathrm{g} \mathrm{DW})^{-1} . \mathrm{cm}^{-2}$ at T25 in upper segments $(P<0.01$; Fig. 1$)$. Fungal biomasses were not significantly different among treatments $\left(70 \mu \mathrm{g}\right.$ C. $(\mathrm{g} D W)^{-1} . \mathrm{cm}^{-2}$ in upper segments and $10 \mu \mathrm{g} \mathrm{C} .(\mathrm{g}$ $\mathrm{DW})^{-1} \cdot \mathrm{cm}^{-2}$ in lower segments) (Fig.1). 
most frequent testate amoebae were Archerella (Amphitrema) flavum (29\%), Nebela

301 tincta (18\%) and Hyalosphenia papilio (18\%) in upper segments and A. flavum (30\%),

302 N. tincta (28\%) and Difflugia bacillariarum (27\%) in lower segments (Table 2). The

303 same species were dominant at T15 with H. papilio (42\%), A. flavum (16\%), and N.

304 tincta (16\%) in upper segments, and A. flavum (29\%), E. strigosa (27\%), and N. tincta

$305(16 \%)$ in lower segments. For T20-T25 communities, the upper segments were

306 dominated by $H$. papilio (35\% and 43\%, respectively) and E. strigosa ( $30 \%$ and $27 \%$,

307 respectively) (Table 2). The biomass of testate amoebae was correlated with the total

308 biomass of other groups added $(\mathrm{r}=0.63, P<0.01)$ in upper segments but not in lower

309 segments $(\mathrm{r}=0.15, P=0.57)$. The density of $E$. strigosa was significantly correlated to

310 the temperature increase $(r=0.62)$, the density of bacteria $(r=0.49)$ and free phenolics

$311(\mathrm{r}=0.58)$ in upper segments of Sphagnum $(P<0.01)$. In lower segments, no species

312 was significantly influenced by the temperature gradient nor free phenolics.

313 The results obtained for flagellates and ciliates strongly varied among treatments

314 in upper and lower segments but no effect of temperature was clearly observed.

316 Relationships between environmental parameters and Sphagnum biota

317 The MFA of the 3 environmental matrices (water chemistry, temperature and phenolics)

318 and the 2 microbial community (upper and lower segments) data sets confirmed the 319 existence of an overall division among the temperature treatments (i.e. T15, T20 and 320 T25) with different global structure of microbial communities (Fig. 2).

In the separate RDAs, T20 and T25 microbial assemblages and T15 microbial 322 assemblage were clearly separated in upper segments (Fig. 3a), while in lower segments 323 the separation between treatments was unclear (Fig. 3b). The models explained 
324 respectively $56.4 \%$ and $27.6 \%$ of the variability in microbial data in upper and lower

325 segments analysis $(P<0.01$ for each axes, Monte-Carlo permutation test, 999

326 permutations). T20 and T25 microbial assemblages (particularly bacteria, fungi and

327 testate amoebae) in upper segments were related with temperature and free phenolics,

328 while microbial assemblage in T15 was related to Eh potential. In lower segments,

329 microbial community structures along the temperature gradient were not clearly

330 separated, except some T20 and T25 replicates correlated with elevated temperatures

331 and the biomass of bacteria.

The successive RDAs on individual environmental variables revealed that the

333 proportion of microbial data explained by each explanatory variable varied among

334 variables both between the environmental data sets and along the 2 vertical positions

335 (Table 3). The overall RDA (upper and lower segments) showed that free phenolics and

336 temperature data sets explained, independently of the other 2 data sets, respectively

$33711.9 \%(P=0.004)$ and $7.6 \%(P=0.02)$ of the microbial data variance. However, the

338 variance explained by these variables was however much higher in the partial RDA's of

339 upper and lower segments (Table 3). For example, temperature explained $42.1 \%$ of the

340 microbial data variance in upper segments $(P<0.001)$ and decreased to $2.5 \%$ in lower

341 segments, while the variance explained by free phenolics increased from $5.2 \%$ to $15.7 \%$

$342 \quad(P<0.05)$ between the upper and lower segments. 
Temperature gradient effect on microbial food web

349 This study is unique in that it addressed the effects of experimental high temperature 350 gradient on microbial communities living in Sphagnum, including different trophic 351 groups. MFA confirmed the existence of 3 microbial community assemblages along the 352 temperature gradient (T15, T20, and T25 microbial assemblages) and the validity of 353 using Sphagnum and its associated microbial communities as an indicator of climate 354 change. Interestingly, the results revealed different behavior of the trophic groups 355 related to the temperature gradient. The biomass of the microbial primary producers 356 (microalgae and cyanobacteria) did not vary at any temperature while an increase of the 357 biomass of the microorganisms (bacteria and testate amoebae) involved in the microbial 358 loop was recorded (dissolved organic matter $\rightarrow$ bacteria $\rightarrow$ heterotrophic protists 359 (ciliates, flagellates, testate amoebae) $\rightarrow$ macrozoorganisms; Gilbert et al., 1998).

Along the temperature gradient, the density and the biomass of testate amoebae

361 in Sphagnum upper segments increased and their community structure changed in 362 heated treatments. These results combined with the significant relation between the 363 biomass of testate amoebae and the total biomass of other groups added suggested that 364 indirect effects on the food-web structure occurred. The significant link between 365 Euglypha strigosa and bacteria along the temperature gradient seemed to confirm this 366 hypothesis. Indeed, Euglypha is described as bacterivorous in literature (Gilbert et al., 367 2000; Beyens et al., 2009). The increase of bacteria density in Sphagnum upper 368 segments probably influenced the abundance of E. strigosa. Beyens et al. (2009) also 369 observed similar results for the correlation between testate amoeba communities and 370 temperature effect. For example, Trachelocorythion and Euglypha genera reacted 
371 positively with heatwave and were linked to the increase of bacteria. The high density

372 and high relative abundance of $H$. papilio in heated treatments also suggested indirect

373 effects on the food-web structure, since this species feed on a wide range of prey, 374 notably small eugliphids (Gilbert et al., 2000, Meisterfeld, 2000a, b). Conversely, the 375 biomass and the density of $N$. tincta did not vary along the temperature gradient. This 376 species was recognized to essentially feed on autotrophic microorganisms during 377 summer (Gilbert et al., 2003), and the biomass of these groups was not affected by the 378 temperature increase. Microbial primary producers (microalgae and cyanobacteria) 379 living in Sphagnum are well known to be sensitive to water chemistry, and to $\mathrm{N}$ and $\mathrm{P}$ 380 addition (Hooper, 1981; Howell and South, 1981; Gilbert et al., 1998). on a wide range of prey, their community integrates the variations of the food web due 383 to environmental perturbations (Gilbert et al., 1998, 2003; Nguyen-Viet et al., 2007; 384 Mitchell et al., 2008). Thus, they could be interesting candidates for monitoring the 385 impact of elevated temperatures in Sphagnum peatlands. On the other hand, to deepen 386 our knowledge about the changes in the microbial food web with elevated temperatures, 387 complementary experiments focusing on the feeding habit progression of testate 388 amoebae would be necessary.

Sphagnum biota - environmental factors relationships

391 Among environmental factors, temperature appeared as the principal factor that 392 determines microbial community variations. Direct gradient analysis (RDA) revealed 393 that in upper segments temperature, Eh potential and conductivity significantly 394 explained a high proportion of microbial data set variations. This result was not 395 surprising since water chemistry generally contributed to a change in microbial 
community distribution that occurred at the top of Sphagnum carpet (Howell and South,

397 1981; Mitchell et al., 2003; Mieczan, 2009). Conversely, in lower segments, only free

398 phenolics significantly explained microbial data variations. Studying both upper and

399 lower segments along a temperature gradient demonstrated that the response of

400 microbial communities to abiotic factors differed between Sphagnum segments. These

401 results illustrate $(i)$ how vertical gradients lead to ecological niches separations in

402 Sphagnum and (ii) the potential influence of phenolic compounds on microbial 403 community distribution.

404 The Sphagnum upper segments were characterized by a higher phenolic content

405 (bound and free) compared to the lower segments, and constituted original results about

406 phenolic repartition in Sphagnum. These results were in accordance with Sphagnum

407 biology, given that capitula constituted the dominant life parts of Sphagnum where

408 main metabolic processes occurred (Clymo and Hayward, 1982). The metabolism of

409 phenolic compounds in Sphagnum was more important at the capitulum layer than in

410 lower segments. The observed correlation between free and bound phenolic compounds

411 demonstrated that their production by Sphagnum was linked and similar. However, only

412 free phenolics were affected by elevated temperature through an increase in top

413 segments. Such result suggested that phenolic content was also affected qualitatively by

414 elevated temperature. Different kinds of phenolics (e.g. phenolic acids and flavonoids)

415 are known to be present in the Sphagnum genus (Rudolph and Samland, 1985; Opelt et

416 al., 2007). To better understand phenolic Sphagnum metabolism under elevated

417 temperatures, it would be necessary to characterize both qualitatively and quantitatively

418 the phenolic extracts from the different segments by using a high-pressure liquid 419 chromatography technique. 
Free phenolics were related to microbial communities and explained a large part

421 of the variance observed, particularly in the lower segments. This relation outlines $(i)$

422 the potential chemical interaction between Sphagnum and microbial communities living

423 in Sphagnum and (ii) the role of such compounds in the structure of microbial

424 communities regardless of their increase at $25^{\circ} \mathrm{C}$ in upper segments. Similar results

425 were found with the testate amoebae community structure (Jassey et al., 2011).

426 Nonetheless, the significant relation between E. strigosa and free phenolics in upper

427 segments suggested a potential direct effect of these compounds on this species since its

428 density did not increase in lower segments while the density of bacteria increased.

429 Although this result does not allow a conclusion to be drawn on a possible direct

430 positive effect of water-soluble phenolic compounds on E. strigosa, it raises the issue of

431 the possible role of such compounds. Recently, $p$-hydroxyl phenolic acids released by

432 Sphagnum mosses have been shown to possess antibacterial and antifungal activity

433 (Opelt et al., 2007; Mellegård et al., 2009). Thus it is possible that water-soluble

434 phenolic compounds released by Sphagnum play a role in microbial assemblages

435 through direct (e.g. physiological) and/or indirect (e.g. through impact on prey-predator

436 relationships) effects.

438 Conclusion

439 This original approach of studying Sphagnum upper and lower segments revealed a 440 strong relationship between microbial community structures and rising temperatures in 441 upper segments of Sphagnum. Because of the different biotic and abiotic gradients in 442 Sphagnum-dominated peatlands, our study highlighted the need to study together 443 different microbial groups along the living parts of Sphagnum. A destabilization of the 
444 microbial food web by elevated temperatures $\left(5^{\circ} \mathrm{C}\right)$ through their trophic relationships is 445 suggested in upper segments. Therefore, microbial assemblages and/or testate amoebae 446 may be useful indicator to monitor climate change in peatlands. The relationships 447 between water-soluble phenolics compounds and microbial communities living in 448 Sphagnum remained an interesting result. Further in situ investigations characterized by 449 a realistic warming and moisture variations should be undertaken.

\section{Acknowledgments}

453 This article is a contribution of the Agence National de la Recherche (ANR) 454 PEATWARM project (Effect of moderate warming on the functioning of Sphagnum 455 peatlands and their function as carbon sink). PEATWARM is supported by the French 456 National Agency for Research under the "Vulnerability: Environment-Climate" 457 Program (ANR-07-VUL-010). V. E. J. Jassey has been supported by a grant from the 458 Franche-Comté Region.

\section{References}

462 Beyens, L., Ledeganck, P., Graae, B. J., and Nijs, I. 2009. Are soil biota buffered against climatic extremes? An experimental test on testate amoebae in arctic tundra (Qeqertarsuaq, West Greenland) [online]. Polar Biol. 32(3): 453-62. doi: 10.1007/s00300-008-0540-y.

466 Borsheim, K. Y. and Bratbak, G. 1987. Cell-volume to cell carbon conversion factors 75. 
Bratbak, G. 1985. Bacterial biovolume and biomass estimations. Appl. Env. Microb. 49(6): 1488-93.

Breeuwer, A., Heijmans, M.M.P.D., Gleichamn, M., Robroek, B. J. M., and Berendse, F. 2009. Response of Sphagnum species mixtures to increased temperature and nitrogen availability [online]. Plant Ecol. 204: 97-211. doi: 10.1007/s11258-0099571-x.

Breeuwer, A., Heijmans, M.M.P.D., Robroek, B. J. M., and Berendse, F. 2008. The effect of temperature on growth and competition between Sphagnum species [online]. Oecologia 156(1): 155-67. doi: 10.1007/s00442-008-0963-8.

Chiapusio, G., Gallet, C., Dobremez, F., and Pellissier F. 2005. Allelochemicals : tomorrow's herbicides ? In Biopesticides of plant origin. Intercept Ltd. Lavoisier Publ. Inc., Hampshire, UK. pp 149-155.

Clymo, R.S. and Hayward, P.M. 1982. The ecology of Sphagnum. In: Bryophyte Ecology. Edited by A.E.J. Smith. Chapman \& Hall, New York. pp. 229-289.

Davidson, E. A. and Janssens, I. A. 2006. Temperature sensitivity of soil carbon decomposition and feedbacks to climate change [online]. Nature 440(7081): 165-73. doi: 10.1038/nature04514.

Escofier, B. and Pages, J. 1994. Multiple factor-analysis (AFMULT package). Comp Stats Data Anal. 18(1): 121-40.

Gallet, C., Lebreton, P. 1995. Evolution of phenolic patterns in plants and associated litters and humus of a mounatin forest ecosystem. Soil Biol. Biochem. 27: 157165.

Gilbert, D., Amblard, C., Bourdier, G., Francez, A.-J., and Mitchell, E. A. D. 2000. Le régime alimentaire des thécamoebiens (Protista, Sarcodina). Ann. Biol. 39 :5768. 
494 Gilbert, D., Amblard, C., Bourdier, G., and Francez, A. J. 1998. The microbial loop at the surface of a peatland: Structure, function, and impact of nutrient input. Microb. Ecol. 35(1): 83-93.

Gilbert, D., Mitchell, E. A. D., Amblard, C., Bourdier, G., and Francez, A. J. 2003. Population dynamics and food preferences of the testate amoeba Nebela tincta major-bohemica-collaris complex (Protozoa) in a Sphagnum peatland. Acta Protozoo. 42(2): 99-104.

501 Gorham, E. 1991. Northern peatlands - Role in the carbon cycle and probable responses to climatic warming. Ecol. Appl. 1(2): 182-95.

503 Hattenschwiler, S. and Vitousek, P. M. 2000. The role of polyphenols in terrestrial 504 ecosystem nutrient cycling. Trends Ecol Evol. 15(6): 238-43.

Hooper, C. A. 1981. Microcommunities of algae on a Sphagnum mat. Holarctic Ecol. 4(3): 201-07.

Howell, E. T. and South, G. R. 1981. Population dynamics of Tetmemorus (Chlorophyta, Desmidiaceae) in relation to a minerotrophic gradient on a Newfoudland fen. Brit. Phycol. J. 16(3): 297-312.

510 Husson, F., Josse, J., Lê, S., and Mazet, J. 2009. FactoMineR: Factor Analysis and Data Mining with R. R package, version 1.12 http://CRAN.Rproject.org/package=FactoMineR.

513 IPCC 2007. Summary for policy makers. In Solomon, S., Qin, D., Manning, M., Chen, Z., Marquis, M., Averyt, K.B., Tignor, M., Millern H.L. (eds) Climate change 2007: the physical science basis summary for policymakers. Contribution of Working Group I to the Fourth Assement report of the Intergovernmental Panel on Climate Change. Cambridge University Press, Cambridge. 
Jassey, V.E.J., Chiapusio, G., Mitchell, E.A.D., Binet, P., Toussaint, M-L., and Gilbert, D. 2011. Fine-scale horizontal and vertical micro-distribution patterns of testate amoebae along a narrow fen/bog gradient [online]. Microb. Ecol. 61(2): 374385. doi: 10.1007/s00248-010-9756-9.

Lamentowicz, M., Lamentowicz, L., van der Knaap, W. O., Gabka, M., and Mitchell, E. A. D. 2010. Contrasting Species-Environment Relationships in Communities of Testate Amoebae, Bryophytes and Vascular Plants Along the Fen-Bog Gradient [online]. Microb. Ecol. 59(3): 499-510. doi: 10.1007/s00248-009-9617-6.

Macheix, J-J., Fleuriet, A. and Jay-Allemand, C. 2005. Les composes phénoliques des végétaux. Un example de métabolites secondaires d'importance économique. Edited by Presses Internationales Polytechnique, Montréal, Que., Can.

Meisterfeld, R. 2000a. Order Arcellinidae, Kent, 1880. The illustrated guide to the protozoa. Edited by J.J. Lee, Leedale G.F., Bradbury P. Society of Protozoologists, Lawrence, Kan., USA. pp. 827-860.

Meisterfeld, R. 2000b. 'Testate amoebae with filopodia. The illustrated guide to the protozoa. Edited by J.J. Lee, Leedale G.F., Bradbury P. Society of Protozoologists, Lawrence, Kan., USA. pp. 827-860. pp. 1054-1084.

Mellegård, H., Stalheim, T., Hormazabal, V., Granum, P. E., and Hardy, S. P. 2009. Antibacterial activity of sphagnum acid and other phenolic compounds found in Sphagnum papillosum against food-borne bacteria [online]. Lett. Appl. Microb. 49(1): 85-90. doi: 10.1111/j.1472-765X.2009.02622.x.

Meyer, C., Gilbert, D., Gaudry, A., Franchi, M., Nguyen-Viet, H., Fabure, J., and Bernard, N. 2010. Relationship of Atmospheric Pollution Characterized by Gas (NO2) and Particles (PM10) to Microbial Communities Living in Bryophytes at Three Differently Polluted Sites (Rural, Urban, and Industrial) [online]. Microb. 
544 Mieczan, T. 2009. Ecology of testate amoebae (Protists) in Sphagnum peatlands of eastern Poland: Vertical micro-distribution and species assemblages in relation to environmental parameters [online]. Inter. J. Limnol. 45(1): 41-49. doi: 10.1051/limn/09003.

Mitchell, E. A. D., Charman, D. J., and Warner, B. G. 2008. Testate amoebae analysis in ecological and paleoecological studies of wetlands: past, present and future [online]. Biodiv. Conserv. 17(9): 2115-37. doi: 10.1007/s10531-007-9221-3.

Mitchell, E. A. D., Gilbert, D., Buttler, A., Amblard, C., Grosvernier, P., and Gobat, J. M. 2003. Structure of microbial communities in Sphagnum peatlands and effect of atmospheric carbon dioxide enrichment. Microb. Ecol. 46(2): 187-99.

Nguyen-Viet, H., Bernard, N., Mitchell, E. A. D., Badot, P. M., and Gilbert, D. 2008. Effect of lead pollution on testate amoebae communities living in Sphagnum fallax: An experimental study [online]. Ecotox. Environ. Saf. 69(1): 130-38. doi: 10.1016/j.ecoenv.2007.02.007.

Nguyen-Viet, H., Gilbert, D., Mitchell, E. A. D., Badot, P. M., and Bernard, N. 2007. Effects of experimental lead pollution on the microbial communities associated with Sphagnum fallax (Bryophyta) [online]. Microb. Ecol. 54(2): 232-41. doi: 10.1007/s00248-006-9192-z.

Oksanen, J., Blanchet, G., Kindt, R., Legendre, P., O'Hara, R. G., Simpson, G. L., Solymos, P., Stevens, M. H. H., and Wagner, H. 2010. 'vegan: Community Ecology Package. $\mathrm{R}$ package version 1.17-1. http://CRAN.Rproject.org/package=vegan .

Opelt, K., Chobot, V., Hadacek, F., Schonmann, S., Eberl, L., and Berg, G. 2007. Investigations of the structure and function of bacterial communities associated 
with Sphagnum mosses [online]. Environ. Microb. 9(11): 2795-809. doi: 10.1111/j.1462-2920.2007.01391.x.

570 Peres-Neto, P. R., Legendre, P., Dray, S., and Borcard, D. 2006. Variation partitioning of species data matrices: Estimation and comparison of fractions. Ecology. 87(10): 2614-25. doi: 10.1890/0012-9658(2006)87[2614:VPOSDM]2.0.CO;2.

Porter, K. G. and Feig, Y. S. 1980. The use of DAPI for identifying and counting aquatic microflora. Limnol. Ocean. 25(5): 943-48.

575 R Development Core Team. 2008. R: A language and environment for statistical computing. $\mathrm{R}$ Foundation for Statistical Computing, Vienna, Austria. http://CRAN.R-project.org/

Rasmussen, S., Peters, G., and Rudolph, H. 1995. Regulation of phenylpropanoid metabolism by exogenous precursors in axenic cultures of Sphagnum fallax. Physiol. Planta. 95(1): 83-90.

Rudolph, H. and Samland, J. 1985. Occurrence and metabolism of sphagnum-acid in the cell walls of Bryophytes. Phytochem. 24(4): 745-749.

Rydin, H. and Jeglum, J. K. 2006. The Biology of peatlands. Edited by Oxford University Press, Oxford, UK.

Schönborn, W. 1986. Population dynamics and production biology of testate amoebae (Rhizopoda, Testacea) in raw humus of two coniferous forest soils. Archiv für Protistenkunde 39: 325-342.

Shaw, A.J., Cox, C.J., and Boles, S.B. 2003. Global patterns in peatmoss biodiversity.

590 Souto, X. C., Bolano, J. C., Gonzalez, L., and Reigosa, M. J. 2001. Allelopathic effects 591 of tree species on some soil microbial populations and herbaceous plants. Biol. Planta. 44(2): 269-75. 
593 Souto, X. C., Chiapusio, G., and Pellissier, F. 2000. Relationships between phenolics

594

595

596

597

598

599

600

601

602

603

604

605

606

607

608

609

610

611

612

613

614

615

616

\section{1} and soil microorganisms in spruce forests: Significance for natural regeneration. J. Chem. Ecol. 26(9): 2025-34.

Spitaler, R., Winkler, A., Lins, I., Yanar, S., Stuppner, H., and Zidorn, C. 2008. Altitudinal variations of phenolic content in flowering heads of Arnica Montana cv. ARBO: a 3-year comparison. J. Chem. Ecol. 34: 369-375.

Ter Braak, C. and Similauer, P. 1998. Canoco reference manual and user's guide to canoco for windows, software for canoco community ordination (version 4). Centre for Biometry Wageningen pp.31-145.

Utermölh, H. 1958. Zur vervollkommnung der quantative phytoplankton-methodik. Mitt. Inst. Verhein Limnol. 9: 1-38

Verhoeven, J. T. A. and Liefveld, W. M. 1997. The ecological significance of organochemical compounds in Sphagnum. Acta Bot. Neerl. 46(2): 117-30.

Waterman, P.G., Mole, S. and Molw, S. 1994. Analysis of phenolic plant metabolites. Blackwell Sience Inc., Walden, Mass. USA.

Weisse, T., Muller, H., Pintocoelho, R. M., Schweizer, A., Springmann, D., and Baldringer, G. 1990. Response of the microbial loop to the phytoplankton spring bloom in a large prealpine lake. Limnol. Ocean. 35(4): 781-94. 
618 Table 1. Total concentrations (mg.g ${ }^{-1}$ DW) of Sphagnum fallax free and bound 619 phenolics in two layers (upper and lower segments) at initial stage (IS) and at the 620 temperatures 15,20 , and $25^{\circ} \mathrm{C}(\mathrm{T} 15, \mathrm{~T} 20$, and $\mathrm{T} 25)(\mathrm{n}=4)$. Letters indicate significant 621 differences of the total phenolic concentrations between the upper and the lower 622 segments for a same treatment $(P<0.05)$ and Asterisk indicates significant difference 623 between temperatures $(P<0.05)$.

624 Table 2. Abundance of 12 testate amoebae species found in upper and lower segments 625 of Sphagnum fallax at initial stage (IS) and grown over an 8 weeks period at 15, 20 and $62625^{\circ} \mathrm{C}(\mathrm{T} 15, \mathrm{~T} 20$, and $\mathrm{T} 25)(\mathrm{n}=4)$. Asterisks indicate significant differences of a same 627 species related to the gradient of temperature in upper and lower segments $(P<0.05)$.

628 Table 3. Summary of redundancy analyses (RDA) on microorganisms and 629 environmental variables: fraction of variance explained (\%) and significance of 630 individual variables taken alone or grouped. 


\section{$644 \quad$ Figures}

645

646 Figure 1. Total carbon biomass $\left(\mu \mathrm{gC} \cdot \mathrm{g}^{-1} \cdot \mathrm{cm}^{-2}\right.$, mean \pm S.E. $)$ of all microbial groups and

647 Carbon biomass $\left(\mu \mathrm{gC} . \mathrm{g}^{-1} \cdot \mathrm{cm}^{-2}\right.$, mean \pm S.E. $)$ of microbial groups in Sphagnum samples 648 analyzed after 8 weeks related to the gradient of temperature. Letters indicate significant 649 differences of biomass between temperatures in upper and lower segments (Friedman 650 test, $P<0.01)$. IS, initial stage

651 Figure 2. Multiple factor analysis (MFA) of the two Sphagnum biota communities and 652 environmental (chemical, physical and phenolics) data sets. Biplot of axes 1 and 2 (both 653 significant at $P=0.001$ ) is given together with the result of a hierarchical agglomerative 654 clustering (grey solid lines) obtained by the Ward method on the Euclidean distance 655 matrix between MFA site scores, showing three main groups of temperature treatment $656($ white symbols $=\mathrm{T} 15$, black symbols $=\mathrm{T} 20$, grey symbols $=\mathrm{T} 25)$.

657 Figure 3. Redundancy analyses (axes 1 and 2) of microbial data in upper segments (a) 658 and lower segments (b). Environmental variables retained after model selection are 659 represented by arrows. Microbial groups are represented by dotted lines. F_phe : free 660 phenolics; Temp: temperature. 